\title{
Economic Growth and Development Effect of Education: Cointegration Analysis for Turkey
}

\author{
Asst.Prof.Dr. Ahmet Oğuz \\ Karabuk University, Faculty of Economics and Administrative Sciences \\ Department of Economics, Karabuk/Turkey \\ ahmetoguz@karabuk.edu.tr
}

Asst.Prof.Dr. Üzeyir Aydin

Dokuz Eylul University, Faculty of Economics and Administrative Sciences

Department of Economics, Izmir/Turkey uzeyir.aydin@deu.edu.tr

\section{Asst.Prof.Dr. Oğuz Kara}

Duzce University, Faculty of Business, Department of Business Administration, Duzce/Turkey

Doi:10.5901/mjss.2014.v5n13p369 oguzkara@duzce.edu.tr

\section{Abstract}

Economic theory proposes that there is a connection between education level and efficiency, and a person contribute to the society related with his education level. Also it is accepted that characteristics of education activities effects economic, social and cultural development of the society. Human capital is of great importance for social and economic progress. Qualified work force is resulted from the education level. Investment for the human capital implied education investments which provide the increase literacy rate and information-ability levels. This is really important for both underdeveloped and developed countries. So education investments should be analyzed for understanding the effects on growth and development. Therefore, the aim of this paper is to investigate the relationship between education investments and economic growth for Turkey. We used cointegration technique for the period from 1980 to 2011.

Keywords: Education, Economic Growth, Development, Turkey, Cointegration

\section{Introduction}

Human capital is the most important production factor from the beginning of the economics theory. But now, the importance of this factor differentiated. Qualified work force is of great importance for the twenty-first century. Qualified work force is resulted from the education level. Investment for the human capital implied education investments.

Education investments provide the increase literacy rate and information-ability levels. This is really important for both underdeveloped and developed countries. Therefore education investments should be analyzed for understanding the effects on growth and development. For these purposes, we tested the long-run relationship between education investments and economic growth using cointegration technique. And then we interpreted the results.

\section{Literature Review for Emprical Analysis}

Economic growth specifies the increase in the economic activities' scale and per capita product, but economic development is related with the wealth level. In the development analysis average education year, expected lifetime, income allocation, nutrition is used to define development level. The relation between economic growth and development is result from the high correlation between the Gross National Product (GNP) and wealth criteria.

Scientific and technical information; enrollment rates, working age population's education levels and education levels of pupils help to increase the economic growth and development in a country (Dura,1999:14). Theorical structure of human investment was started by the T.W. Schultz. And then Denison, Becker, Harbison, Myers, Mincer, Psacharopoulos and R.J.Barro gave important contributions about human capital investment. 
Schultz (1968) defined human capital investment as a useful abilities accumulation (Schultz, 1968: 277). According to this, human capital investments increase the production and efficiency. Therefore economic growth provides to increase economic growth, so human capital investments are important.

Education has consumption and production properties. The money which is paid for the education expenses is the consumption side of the education. On the other hand, educated people's increased productivity and contribution to the economic growth is the production side of the education. Because of these factors, increase in per capita income is related with human capital investments.

Denison (1962)'s growth approach is based on Cobb-Douglas production function. He investigated the relationship between development and education. He used growth accounting technique. This technique implies that if economic growth is related with capital and labor force, growth rates can be divided of these two factors. He found that the $\% 23$ percent of USA's economic growth rates were explained by the increase in the education level of labor force.

Psacharopoulos (1981) found that investments for the primary school enrollment at the less developed and developing countries had greater contribution than investments for the secondary school enrollment. Asteriou and Agiomirgianakis (2001) did time series analysis for Greece, and found cointegration between per capita income and primary, secondary and higher education enrolment rate. According to the Barro (1991), human capital is an important effect on economic growth. Based on the initial level of per capita GDP and policies of countries, when years of schooling increases, they growth fast. If developing countries increase human capital investments they can catch the developed countries.

There are some important contributions for Turkey. Studies which consider types of education and economic structure show that there is a strong relationship between per capita income and education type. They don't find correlation between income level and primary or secondary school, but they found strong relationship between income level and higher education. In addition to this, changes in the economic structure cause to change education's structure. For this reason, developing countries which establish new industries with transferring new technologies from the developed countries will be need educated work force.

\section{Cointegration Analysis for Turkey}

In this paper for the cointegration results between the economic growth and education, we used Johansen and Juselius $(1988,1990)$ test. Our model is:

$g d p_{t}=a_{0}+a 1 e h a r_{t}+u_{t}$

ehar: education share of the budget

gdp: per capita reel GDP

$u$ : residual term

If residual term is stationary, there is a long run relationship between the variables. However in case of short run, there is a error- correction mechanism which known as correcter the fault. (Engle and Granger, 1987).

In this context ECM $\Delta g d p_{t}=a_{0}+a_{1} \Delta e h_{r_{11}}+\delta u_{t 1}$ is formed as and if the coefficient of the error-correction term is statistically significant ,to see error-correction models (ECMs) work. Although Engle-Granger fairly easy to implement, approach has been criticized in some respects ${ }^{1}$.

In this study, the value of variables given annually. This values are secondary and involves the term of 1980-2011. These datas are gathering from Turkish Statistical Institute (TurkStat) and Central Bank Electronic Data Distribution System and given in the table below. While the econometric estimates make, the logarithm of this variables take at the same time.

Table 1. Variables and Definitions

\begin{tabular}{|c|l|}
\hline Gdp & Gross domestic product per capita \\
\hline prsec & Primary schooling rate \\
\hline high & Secondary schooling rate \\
\hline highe & Higher schooling rate \\
\hline ehar & Education expenditure in budget \\
\hline
\end{tabular}

\footnotetext{
${ }_{1}^{1}$ The approach that takes into account the criticism to the Engle-Granger approach and other widely used method is the Johansen cointegration approachFor more information; Johansen, 1988; Johansen and Juselius, 1900. 


\subsection{Emprical Findings}

In order to determine the direction of causality between variables, the first thing to be done, whether a long-term relationship between these variables is to determine. In other words, cointegration between education variables and economic growth (if any) must be determined. To do this, features of the time series of the variables are of great importance. Because while any problem is not observed in the results from the used series of stationary series, using non-stationary series may lead to obtain unreliable and economically difficult to interpret results. Therefore, before research the presence of cointegration, the time series properties of the variables used in the analysis are to be studied.

Features of the time series of the data was examined with Dickey-Fuller (DF) and Augmented Dickey-Fuller (ADF) unit root test that are commonly used (Gujarati, 1999, Kutlar, 1998). DF and ADF unit root test results are given in Table 2.

Table 2. DF and ADF Unit Root Tests

\begin{tabular}{|c|c|c|c|c|}
\hline Explanatory Variables & Coefficient $t$-stat. & Delay Level & Critical Value & Result \\
\hline$\Delta \log$ gdp & $-5,79$ & 0 & $-3,7119$ & Stable \\
\hline$\Delta \log$ prsec & $-4,94$ & 0 & $-3,7119$ & Stable \\
\hline$\Delta \log$ highe & $-4,98$ & 1 & $-3,7347$ & Stable \\
\hline$\Delta \log$ high & $-3,75$ & 0 & $-3,0521$ & Stable \\
\hline$\Delta \log$ ehar & $-3,97$ & 0 & $-3,0521$ & Stable \\
\hline
\end{tabular}

As can be observed in table 2; According to the ADF test results, all of the variables in the system, have first-difference stationary process. Accordingly; _ has a unit root in levels, but stagnated in the first differences of the variables, cointegration relationship can be ascertained.

Cointegration relationship, are both handled in the aggregate and, separately. Test results of the variables and the delay level can be viewed through the Table 3 , because of the yearly cost is included and they are stabilized with the first difference. . Likelihood Ratio (LR) test indicates between the variables presence of the vector in two cointegrate. Accordingly; GDP per capita and higher education enrollment ratio GDP per capita and high school enrollment rate , according to the LR statistics, a long-term relationship is observed and margin of error of the equation is followed by a white-noise process.

Table 3. Cointegration Test Results

\begin{tabular}{|c|c|c|c|}
\hline Null Hypothesis & Alternative Hypothesis & TraceTest Statistics & $5 \%$ Critical Value \\
\hline $\mathrm{r}=0$ & $\mathrm{r} \geq 1$ & 72.226 & 53.12 \\
\hline $\mathrm{r}=1$ & $\mathrm{r} \geq 2$ & 38.039 & 34.91 \\
\hline $\mathrm{r}=2$ & $\mathrm{r} \geq 3$ & 17.000 & 19.96 \\
\hline
\end{tabular}

The results of the Gdp and variables separately observed cointegration tests, can be viewed in Table 4. In the Table resid1, resid2, resid8 resid4 respectively; refers to the GDP's residuals that are obtained from highe, ehar, high and prsec regressions. Resid5; highe-gdp, resid6; high-gdp, resid7; ehar-gdp and resid9 indicates the residuals that are obtained from prsec-gdp regression.

Accordingly; The relationship between the variable gdp-hisghe and gdp-high is observed cointegration. We can define resid1 and resid5 which are derived from the observed residues of cointegration relationships between gdp and highe(resid1), gdp and high(resid5). So following equations are Error-Correction regression.

Table 4. Cointegration Test Results That Variables Considered Separately

\begin{tabular}{|c|c|c|c|c|c|c|c|c|}
\hline \multicolumn{7}{|c|}{} \\
\hline Variables & Resid1 & Resid2 & Resid4 & Resid5 & Resid6 & Resid7 & Resid8 & Resid9 \\
\hline Gdp & $-3.5750^{*}$ & -1.8387 & $-2.7459^{*}$ & & & & 2.7879 & \\
\hline Highe & & & & $-2.9696^{*}$ & & & & \\
\hline High & & & & & $-4.4535^{*}$ & & & \\
\hline ehar & & & & & & -3.1622 & & \\
\hline prsec & & & & & & & \\
\hline
\end{tabular}


$\Delta \log G d p_{t} \equiv r e s i d 1_{t-1}+d \log G d p_{t-5}+d \log h i g h e_{t-5}+u_{t}$

$\Delta \log$ highe $_{t} \equiv$ resid $_{t-1}+d \log G d p_{t-5}+d \log$ highe $_{t-5}+u_{t}$

As can be seen from Table 5; according to the results from the equation; as resid1 variable coefficient was significant, long-term relationship between the two variables will be considered. Likewise because t statistic of the resid5 was significant, there there is a long term relationship between variables. The same results also, applies to resid6 and resid4 obtained from the gdp-high regressions .

Table 5. Error-Correction Model

\begin{tabular}{|c|c|c|}
\hline & \multicolumn{2}{|c|}{ Dependent Variables } \\
\hline Independent Variables & dloggdp $_{\mathrm{t}}$ & dloghighe $_{\mathrm{t}}$ \\
\hline resid1(-1) & $-1.6831(-4.6331)$ & $-0.3320(-2.9158)$ \\
\hline resid5(-1) & $-0.4310(-2.2210)$ & $0.5414(1.7481)$ \\
\hline highe(-1) & $0.6931(2.5441)$ & $-0.0511(-0.1282)$ \\
\hline gdp(-1) & $0.8338(2.9426)$ & $0.2149(0.5923)$ \\
\hline gdp(-2) & $0.8316(2.9339)$ & \\
\hline gdp(-3) & \multicolumn{2}{|c|}{ Dependent Variables } \\
\hline gdp(-4) & Gdp & high \\
\hline & $-1.9172(-3.8061)$ & $-0.3016(-1.7341)$ \\
\hline Independent Variables & & $-0.3973(-1.4388)$ \\
\hline & $0.9991(2.2181)$ & $-0.0613(-0.2579)$ \\
\hline resid4(-1) & $1.3413(2.9613)$ & $0.9088(4.5988)$ \\
\hline resid6(-1) & $0.6247(2.4056)$ & \\
\hline gdp(-1) & $-0.4217(-1.3140)$ & \\
\hline gdp(-2) & Note: (t-statics) & \\
\hline high(-1) & & \\
\hline high(-2) & & \\
\hline &
\end{tabular}

According to the results of the error-correction model, there is a mutual long-term causal relationship between the gdphigh and gdp-highe. Granger causality relationship between the other variables and gdp can be monitored from Table 6 .

Table 6. Granger CausalityTest Results

\begin{tabular}{|c|c|}
\hline & F - statics \\
\hline prsec $\rightarrow$ gdp & 2.3262 \\
\hline gdp $\rightarrow$ prsec & $3.7528^{*}$ \\
\hline ehar $\rightarrow$ gdp & 0.4283 \\
\hline gdp $\rightarrow$ ehar & 0.5678 \\
\hline${ }^{*}$ Reject the hypothesis of there is no causality \\
\hline
\end{tabular}

As can be observed from the results presented in Table 6 -when taken four delay- only per capita GDP, has a Granger causal effect on the primary school enrollment rate.

\section{Conclusion}

The empirical results obtained from Turkey's annual data for the period 1980-2011, reveals the direction of causality vary according to the variables used. However, in detailed observations, between higher education and high school enrollment rate; and per capita national income long-term relationships were found. Also, according to causal relationship which we investigateby the error-correction model, mutual casual relationship was observed between mentioned variables. According to Granger causality test, only per capita national income has a causal effect on primary school enrollment rates. In short, enhancing aspects of education has been shown on economic growth. All of these results clearly shows us that, the funds allocated to education in the demographic structure, is extremely important elements for Turkey economic development. As subject has a social content, it imposes important responsibilities the state in this area. 
Therefore, with the young and dynamic demographic structure, as a human capital-rich country, Turkey needs efficiencient education developments and enhancing social policies for avid and sustainable way of execution, for a growing Turkey. In other words, Turkey prepared to join the European Union needs to devote more resources to education considering with the rapid population growth and young population. Turkey in parallel with macro-economic stability, should correct the omissions of the years with devoting more resources to the education. This situation undoubtedly, will contribute to be perceived as an advantage for the EU's future with the abilities, knowledge, education level and new technology adaptation points; rather than to be feared view with its population.

\section{References}

Asteriou, D. - G.M. Agiomirgianakis (2001). Human Capital and Economic Growth Time Series Evidence From Greece. Journal of Policy Modeling, 23, pp.481-489.

Barro, R. J. (1991). Economic Growth in A Cross Section of Countries. Quarterly Journal of Economics, 106, May, pp.407-443.

Denison,E.W.(1962). Education,Economic Growth and Gaps in Information. The Journal of Political Economy, Vol:LXX,No:5,Part:2,pp.124-128.

Dickey, D.A.- W.A. Fuller (1979). Distribution of the Estimators for Autoregressive Time Series with A Unit Root. Journal of the American Statistical Association, 74, pp.427-431.

Dickey, D.A.- W.A. Fuller (1981).Likelihood Ratio Statistics for Autoregressive Time Series with A Unit Root. Econometrica,49, pp.10571072.

Dura, C. (1999). Bilgi Toplumuna Doğru Eğitimde Temel Eğilimler (Key Trends Towards Knowledge Society in Education). Erciyes Üniversitesi İlBF Dergisi, S:14, Kayseri, s.1-15.

Dursun, H. (1998). İnsan Sermayesi ve Ekonomik Büyüme (Human Capital and Economic Growth). Hazine Dergisi, S:10/Nisan, Ankara, S.81-98.

Enders, W. (1995). Applied Econometric Time Series. Wiley, New York

Engle, RF. and Granger C.W.J. (1987). Co-integration and Error Correction: Represen-tation, Estimation and Testing. Econometrica, 55, 251-276.

Granger, C.W.J. (1969). Investigating Causal Relations by Econometric Models and Cross-Spectral Methods. Econometrica, 37, 24-36.

Granger, C.W.J. (1986). Developments in the Study of Cointegrated Economic Variab-les. Oxford Bulletin ofEconomics and Statistics, $48,213-228$.

Granger, C.W.J. (1988). Some Recent Developments in a Concept of Causality. Journal of Econometrics ,39, 199-211.

Gujarati, D.M. (1999). Temel Ekonometri (Basic Econometrics), Çeviren: Ü. Şenesen ve G.G. Şenesen. Literatür Yayıncılık: İstanbul.

Psacharopoulos, G. (1981). Returns to Education:An Updated International Comparison. Comparative Education, 17, No:3, pp.321-341.

Psacharopoulos, G. (1985). Returns to Education:A Further International Update and Implications. The Journal of Human Resources, February, pp.583-604.

Saatçi, M. (1985). Eğitim Harcamalarının Verimliliği Üzerine Türkiye Için Yapılan Araştırmalar (Efficiency of Education Expenditure on Research For Turkey). Erciyes Üniversitesi IïBF Dergisi, S:7/Temmuz, Kayseri.

Schultz, T. W. (1968). Education and Economic Growth: Return to Education. Readings in the Economics of Education. UNESCO, France, pp.277-292.

Stewart, F. (1995). Eğitim ve Uyum: 1980'lerin Deneyimi ve 1990'lar İ̧in Bazı Dersler (Experience of the 1980s and Some Lessons for 1990). Piyasa Güçleri ve Küresel Kalkınma, çev: İdil Eser, 1.Baskı, Yapı Kredi Yayınları, İstanbul.

Tunç, M. (1993). Türkiye'de Eğitimin Ekonomik Kalkınmaya Etkisi (Impact on Economic Development of Education in Turkey). 9 Eylül Üniversitesi İ̈BF Dergisi, C:8, S:2, İzmir, s.1-32. 